\title{
Association of maternal plasma or serum zinc concentration with the birth weight of the child
}

\author{
Girija C. Bellad, Laxmi K. S.*
}

Department of Obstetrics and Gynecology, Belagavi Institute of Medical Sciences, Belagavi, Karnataka, India

Received: 23 October 2018

Accepted: 28 November 2018

\section{*Correspondence:}

Dr. Laxmi K. S.,

E-mail: researchguide86@gmail.com

Copyright: (C) the author(s), publisher and licensee Medip Academy. This is an open-access article distributed under the terms of the Creative Commons Attribution Non-Commercial License, which permits unrestricted non-commercial use, distribution, and reproduction in any medium, provided the original work is properly cited.

\begin{abstract}
Background: Zinc is a divalent cation first isolated in 1509 and since then its importance has been increasingly recognised in human health and nutrition. Present study has been undertaken to confirm the association between maternal plasma or serum zinc concentration and birth weight.

Methods: Present study was cross-sectional study conducted in tertiary care hospital. Newborns with a birth weight of $<2.5 \mathrm{~kg}$ and their mothers labelled as study group while newborns with a birth weight of $>2.5 \mathrm{~kg}$ and their mothers were considered as control group. The analysis for the serum concentration of zinc was done using the Atomic Absorption Spectrophotometric method (AAS), this method analytically the most reliable for routine assessment of serum zinc levels. The results deduced from the analysis were accordingly grouped to the study group / control group. We had a sub-group analysis based on the gestational age, as Preterm and Term.

Results: Maternal serum levels of zinc $67.04 \mu \mathrm{g} / \mathrm{dl} \pm 16.66$, in the study group, was less as compared to the maternal serum levels of zinc in the control group with a mean level of $75.39 \mu \mathrm{g} / \mathrm{dl} \pm 17.89$. The results show a significant association between zinc levels and birth weight. Mean Maternal serum levels of zinc $67.04 \mu \mathrm{g} / \mathrm{dl} \pm 16.66$, in the study group, was less as compared to the maternal serum levels of zinc in the control group with a mean level of 75.39 $\mu \mathrm{g} / \mathrm{dl} \pm 17.89$. The results show a significant association between zinc levels and birth weight.

Conclusions: Present study showed a positive correlation of maternal zinc levels with birth weight and prematurity. Hence, we recommend routine zinc supplementation could be included with other nutritional supplements during pregnancy.
\end{abstract}

Keywords: Birth weight, Cross-sectional pregnancy, Zinc

\section{INTRODUCTION}

Zinc is a divalent cation first isolated in 1509 and since then its importance has been increasingly recognised in human health and nutrition. Zinc is known as one of the life's essential elements because of its vital role in a wide range of biological activities.

Although severe zinc deficiency is now considered rare, mild to-moderate zinc deficiency may be relatively common throughout the world. Women are at increased risk of zinc deficiency during pregnancy because of high fetal requirements for zinc. ${ }^{1-4}$ Severe maternal zinc deficiency has been associated with poor fetal growth, spontaneous abortion and congenital malformations, whereas milder forms of zinc deficiency have been associated with low birth weight (LBW), intrauterine growth retardation, and preterm delivery.

Importantly, milder forms of zinc deficiency have also been related to complications of labor and delivery, including prolonged or inefficient first-stage labor and protracted second-stage labor, premature rupture of membranes (PROM), and the need for assisted or operative delivery. These complications in turn impair maternal and perinatal health because they lead to 
increased risk of maternal infections, fetal distress, stillbirth, neonatal asphyxia, and neonatal sepsis., 5

Women are at increased risk of zinc deficiency during pregnancy in part because of high fetal requirements for zinc, and maternal zinc deficiency has been associated with poor fetal growth in both animal and human populations.

However, the research relating maternal zinc status and birth weight has not produced consistent results. Majority of these studies were performed in developed countries. ${ }^{7-}$ 10

Unlike in developed countries, where preterm is the main cause of low birth weight, in developing countries most low birth weight infants are small for gestational age. Low zinc concentrations in the cord blood of low birth weight newborns have been noted in a number of settings and birth weight has been shown to be highly correlated with cord zinc concentration. ${ }^{11}$

In India, where there is a high incidence of low birth weight, it will be interesting to know the role of zinc in newborn and their mothers in relation to birth weight and gestation, especially when there have been studies suggesting zinc as one of the significant predictors of low birth weight. This study has been undertaken to confirm the association between maternal plasma or serum zinc concentration and birth weight.

\section{METHODS}

We conducted a cross sectional prospective study at the Tertiary hospital, over a period of one year.

\section{Inclusion criteria}

- Term newborns.

- Preterm newborns.

- IUGR babies.

- Serum samples of Mothers in good health.

\section{Exclusion criteria}

- Mothers on drugs (diuretics, anticonvulsants, anticoagulants)

- Mothers with clinical conditions known to affect mineral metabolism such as severe malnutrition, severe anaemia (haemoglobin $<10 \mathrm{gm} \%$ ), diabetes mellitus, parathyroid, bone and gastrointestinal diseases.

- The gestational age in present study was calculated using the maternal dates and the Dubowitz scoring. We included 50 newborns with a birth weight of < $2.5 \mathrm{~kg}$ (included preterm, term IUGR) and their mothers. All the subjects in this group met our inclusion criteria, we labelled this group as the 'Study group'. Similarly, we included newborns with birth weight $>2.5 \mathrm{~kg}$ and their mothers, who fulfilled the inclusion criteria, the subjects of this group were labelled as the 'Control group'.

At the time of admission to the labour ward, $2 \mathrm{ml}$ of blood was collected from the peripheral vein of the mother after consent; the samples were collected in a sterile EDTA container and labelled, the samples were immediately sent to the laboratory and centrifuged at 3000rpm for 20min. the supernatant serum was collected in a separate sterile polyethylene container and labelled, the sample was stored at $-20^{\circ} \mathrm{C}$ until analysis.

Similarly, the cord blood was collected immediately after the delivery and was sent to the laboratory in sterile EDTA vacutainer with labelling. The cord blood samples were centrifuged at $3000 \mathrm{rpm}$ for $20 \mathrm{~min}$ and the supernatant serum was collected in a sterile polyethylene container and labelled.

The samples were grouped with the maternal samples. The maternal serum samples and the corresponding cord blood samples were labelled as a set and were taken up for analysis.

The analysis for the serum concentration of zinc was done using the Atomic Absorption Spectrophotometric method (AAS), this method analytically the most reliable for routine assessment of serum zinc levels.

\section{Principle of the method}

Nitro-PAPS react with zinc in alkaline solution to form a purple coloured complex, the absorbance of which is measured at $575 \mathrm{~nm}$. (Interference from copper and iron are virtually eliminated by $\mathrm{ph}$ and chelating additives). The results deduced from the analysis were accordingly grouped to the study group / control group. We had a subgroup analysis based on the gestational age, as Preterm and Term. The results obtained were correlated as per the objective of present study.

\section{Statistical analysis}

Statistical analysis was performed using SPSS 16.0 software. Unpaired t-test was used to analyze continuous data. Categorical data was compared using Chi-square test. $\mathrm{P}<0.05$ was taken as statistically significant. Relative risk was calculated for abnormal UA PI, UA RI, UA S/D, MCA PI and cerebral-umbilical PI ratio. Multivariate regression was used to analyze effect of multiple variables.

\section{RESULTS}

A prospective study conducted at the tertiary hospital over a span of one year. We had enrolled 200 newborns and the mothers as per our inclusion criteria. In the present study most of the mothers were belongs to age group of 21-25 years and majority of the mother had normal delivery (Table 1). 
Table 1: Maternal characteristics.

\begin{tabular}{|l|l|}
\hline $\begin{array}{l}\text { Mother details } \\
\text { Age of mother (years) }\end{array}$ & Number \\
\hline $18-20$ & 14 \\
\hline $21-25$ & 96 \\
\hline $26-30$ & 68 \\
\hline More than 30 & 22 \\
\hline Mode of delivery & \\
\hline Normal & 132 \\
\hline LSCS & 68 \\
\hline Total & 200 \\
\hline
\end{tabular}

The newborns enrolled were randomized into two equal groups based on the birth weight. Newborns with a birth weight of $<2.5 \mathrm{~kg}$ were categorized as the 'study group'. Among the 100 newborns in the study group we had 40 preterm babies and the rest 60 newborns were term IUGR. 100 Newborns with birth weight of $>2.5 \mathrm{~kg}$ were included in the control group; the babies in the control group were term AGA. In present study we found that the mean Maternal serum levels of zinc $67.04 \mu \mathrm{g} / \mathrm{dl} \pm 16.66$, in the study group, was less as compared to the maternal serum levels of zinc in the control group with a mean level of $75.39 \mu \mathrm{g} / \mathrm{dl} \pm 17.89$. The ' $\mathrm{P}$ ' value of 0.031 and the Pearsons correlation coefficient (r) of 0.44 was statistically significant. The results show a significant association between zinc levels and birth weight (Table 2).

Table 2: Zinc levels of maternal serum according to birth weight of baby.

\begin{tabular}{|lllll|}
\hline $\begin{array}{l}\text { Birth } \\
\text { weight }\end{array}$ & \multicolumn{3}{c|}{ Maternal serum-Zinc $($ ugm/dl) } & 'P' \\
\hline & $\begin{array}{l}\text { Min- } \\
\text { max }\end{array}$ & Mean \pm SD & $\mathbf{9 5 \%}$ CI & value \\
\hline $\begin{array}{l}\text { Study } \\
\text { group }\end{array}$ & $26-114$ & $67 \pm 16.6$ & $61.45-69.24$ & \\
$\begin{array}{l}\text { Control } \\
\text { group }\end{array}$ & $41-146$ & $82.35 \pm 19.45$ & $76.6-88.64$ & \\
\hline
\end{tabular}

In present study we compared the zinc levels of the cord blood with birth weight of the baby and we found that zinc levels of the cord blood in the control group (mean zinc levels: $82.35 \pm 19.45)$ were significantly higher than the study group (mean: $75.39 \pm 17.89$ ).

Table 3: Zinc levels of cord blood according to birth weight of baby.

\begin{tabular}{|c|c|c|c|c|}
\hline \multirow{2}{*}{$\begin{array}{l}\text { Birth } \\
\text { weight }\end{array}$} & \multicolumn{3}{|c|}{ Cord blood-Zinc (ugm/dl) } & \multirow{2}{*}{$\begin{array}{l}\text { 'P' } \\
\text { value }\end{array}$} \\
\hline & Min-Max & Mean \pm SD & $95 \% \mathrm{CI}$ & \\
\hline $\begin{array}{l}\text { Study } \\
\text { group }\end{array}$ & $40-124$ & $75.39 \pm 17.89$ & $73.12-84.26$ & \multirow{2}{*}{0.001} \\
\hline $\begin{array}{l}\text { Control } \\
\text { group }\end{array}$ & 49-149 & $82.35 \pm 19.45$ & $91.26-101.23$ & \\
\hline
\end{tabular}

These differences in the mean values were statistically significant (Table 3).

\section{DISCUSSION}

Zinc is a component of a large number of metalloenzymes and there is a high concentration of zinc in the brain. The consequences of zinc deficiency are several with severe impact on human health. ${ }^{5}$ Severe maternal zinc deficiency has been associated with poor fetal growth, spontaneous abortion and congenital malformations (anencephaly), whereas milder forms of zinc deficiency have been associated with low birth weight (LBW), intrauterine growth retardation, and preterm delivery. ${ }^{12}$ Importantly, milder forms of zinc deficiency have also been related to complications of labor and delivery, including prolonged or inefficient first-stage labor and protracted second-stage labor, premature rupture of membranes (PROM). ${ }^{2}$

In present study we found the mean zinc levels in maternal serum in the 'study group': $67 \pm 16.6 \mu \mathrm{gm} / \mathrm{dl}$, were less as compared to mean values of the 'control group': $82.35 \pm 19.45 \mu \mathrm{gm} / \mathrm{dl}$. The difference in mean values was statistically significant. The results were in concordance with other studies done by Neggers et al, Crosby et al, Lalita Bahl et al, Maral et al. The results show, zinc levels have a positive association with birth weight and LBW babies had lower levels of zinc, which might be an independent factor influencing birth weight.

We correlated cord blood levels of zinc with the birth weight of the newborns. The mean cord blood levels of zinc in the study group: $75.39 \pm 17.89 \mu \mathrm{gm} / \mathrm{dl}$, was comparatively less than the control group: $82.35 \pm 19.45$ $\mu \mathrm{gm} / \mathrm{dl}$. The difference in values was statistically significant and had a Pearson's correlation value of 0.42 . Our results were in conformity with other similar studies done by Lalita Bahl et al, A.S.M Iqbal et al, Jeswani and Vani et al, Elizabeth et al. The researchers in their study found a similar association between cord blood, levels of zinc and low birth weight. ${ }^{7,8}$

The results of present study show, Low serum zinc is a significant predictor of low birth weight, if the results are replicable, they will have important implications for both the prediction of low birth weight and possibly the prevention of low birth weight.

\section{CONCLUSION}

Authors in present study found the following observations: The maternal serum zinc levels were significantly higher in the control group as compared to the study group. The cord blood levels of zinc were significantly higher in the control group as compared to the study group. Present study showed a positive correlation of maternal zinc levels with birth weight and prematurity. Hence, we recommend routine zinc supplementation could be included with other nutritional 
supplements during pregnancy. This might help reduce the incidence of prematurity and low birth weight.

Funding: No funding sources Conflict of interest: None declared

Ethical approval: The study was approved by the Institutional Ethics Committee

\section{REFERENCES}

1. Prasad AS: Zinc deficiency in women, infants and children. J Am Coll Nutri. 1996;15(2):113-20.

2. Etemad K, Yavari P, Mehrabi Y, Haghdoost A, Motlagh ME, Kabir MJ, et al. Inequality in utilization of in-patient's health services in Iran. Int J Prev Med. 2015;6:45.

3. Moradi-Lakeh M, Vosoogh-Moghaddam A. Health sector evolution plan in Iran; equity and sustainability concerns. Int J Health Policy Manag. 2015;4(10):637-40.

4. Moradi-Lakeh M, Namiranian N. Increasing trend of low birth weight in rural areas of Iran: a warning. Iran J Pediatr. 2013;23(1):123-4.

5. Caulfield LE, Zavaleta N, Shankar AH, Merialdi M: Potential contribution of maternal zinc supplementation during pregnancy to maternal and child survival. Am J Clini Nutri 1998;68(2):499S508S.

6. Vinayak M: Comparison Of Maternal Serum And Neonatal Cord Blood Levels Of Zinc In Relation To Birth Weight And Period Of Gestation. 2009.

7. King JC: The risk of maternal nutritional depletion and poor outcomes increases in early or closely spaced pregnancies. J Nutri. 2003;133(5):1732S-6S.
8. Erenel H, Mathyk BA, Sal V, Ayhan I, Karatas S, Koc Bebek A. Clinical characteristics and pregnancy outcomes of Syrian refugees: a case-control study in a tertiary care hospital in Istanbul, Turkey. Arch Gynecol Obstet. 2017;295(1):45-50.

9. Linsell L, Malouf R, Morris J, Kurinczuk JJ, Marlow N. Prognostic factors for cerebral palsy and motor impairment in children born very preterm or very low birthweight: a systematic review. Dev Med Child Neurol. 2016;58(6):554-69.

10. Black RE, Victora CG, Walker SP, Bhutta ZA, Christian P, de Onis M, et al. Maternal and child undernutrition and overweight in low-income and middle-income countries. Lancet. 2013; 382(9890):427-51.

11. Osendarp SJ, Van Raaij JM, Darmstadt GL, Baqui AH, Hautvast JG, Fuchs GJ: Zinc supplementation during pregnancy and effects on growth and morbidity in low birthweight infants: a randomized placebo-controlled trial. The Lancet 2001; 357(9262):1080-5.

12. Palomba S, Santagni S, Daolio J, Gibbins K, Battaglia FA, La Sala GB et al Obstetric and perinatal outcomes in subfertile patients who conceived following low technology interventions for fertility enhancement: a comprehensive review. Arch Gynecol Obstet. 2018:1-15.

Cite this article as: Bellad GC, Laxmi KS. Association of maternal plasma or serum zinc concentration with the birth weight of the child. Int $\mathbf{J}$ Reprod Contracept Obstet Gynecol 2019;8:219-22. 